\title{
EKSTRAK BIJI PETAI (PARKIA SPESIOSA HASSK) SEBAGAI HEPATOPROTEKTOR BERDASARKAN KADAR SGPT, SGOT DAN HISTOLOGI HATI TIKUS PUTIH JANTAN YANG DIINDUKSI CCL4
}

\author{
Sediarso $^{1)}$, Erwin Saputra ${ }^{2)}$, Kriana Efendi ${ }^{3)}$ \\ ${ }^{1 *}$ Universitas MH Thamrin \\ ${ }^{2)}$ Universitas Muhammadiyah Prof. DR. Hamka \\ sediarso@yahoo.com
}

\begin{abstract}
ABSTRAK
Biji petai (Parkia spesiosa Hassk) diketahui mengandung zat antioksidan. Antioksidan bersifat dapat menangkal radikal bebas dan dapat digunakan sebagai hepatoprotektor. Penelitian ini dilakukan untuk mengetahui efektivitas ekstrak biji petai sebagai hepatoprotektor. Pada penelitian ini digunakan tikus putih Rattus norvegicus sebanyak 6 kelompok, masingmasing terdiri dari 4 ekor tikus. Kelompok pertama sebagai kontrol normal, kedua sebagai kontrol positif yang diberi obat pebanding kurliv plus, ketiga sebagai kontrol negatif, selanjutnya kelompok keempat, kelima dan keenam berturut-turut diberi ekstrak $50 \mathrm{mg} / 200 \mathrm{~g}$ BB (dosis 1), $100 \mathrm{mg} / 200 \mathrm{~g}$ BB (dosis 2), dan $200 \mathrm{mg} / 200 \mathrm{~g}$ BB (dosis 3). Perlakuan ini selama 7 hari, kemudian pada hari kedelapan diinduksi dengan karbon tetraklorida, dan pada hari kesembilan diambil darahnya untuk ditetapkan kadar SGPT dan SGOT serta dilakukan pembedahan untuk diukur diameter vena sentralisnya. Data yang didapat adalah kadar SGPT, SGOT dan diameter vena sentralis hati. Dari data yang didapat diuji secara statistik menggunakan uji anova dan dilanjutkan dengan uji Tukey HSD, hasilnya menunjukkan bahwa ekstrak biji petai memiliki efektivitas sebagai hepatoprotektor pada dosis $200 \mathrm{mg} / 200 \mathrm{~g} \mathrm{BB}$ (dosis 3) berdasarkan kadar SGPT, SGOT dan kerusakan vena sentralis hati. Dapat disimpulkan bahwa ekstrak biji petai mempunyai efektivitas sebagai hepatoprotektor pada dosis $200 \mathrm{mg} / 200 \mathrm{~g}$ bb yang setara dengan obat pembanding kursiv plus.
\end{abstract}

Kata kunci : Biji Petai, SGPT dan SGOT, Histologi Hati

\section{PENDAHULUAN}

Hati merupakan organ yang cukup penting pada manusia. Hati memiliki berat sekitar $1,5 \mathrm{~kg}$ atau $2 \%$ dari berat badan normal. Hati terletak di bagian atas abdomen sebelah kanan di bawah diafragma (Baradero 2008). Fungsi hati antara lain sebagai alat sekresi, metabolisme, tempat penyimpanan seperti glikogen, lemak, serta zat besi yang disimpan sebagai ferritin, detoksifikasi, serta dapat membentuk dan menghancurkan sel darah merah selama 6 bulan masa kehidupan fetus yang kemudian diambil alih oleh sumsum tulang belakang (Setiadi 2007). Oleh karena itu hati harus di jaga kesehatannya agar terhindar kerusakan atau gangguan-gangguan hati seperti hepatitis, nekrosis hati, serosis hati, steatosis hati (perlemakan hati). Kerusakan-kerusakan hati ini dapat disebabkan oleh beberapa faktor antara lain virus (hepatitis), mengkonsumsi alkohol yang berlebih, penggunaan obat- obatan hepatotoksik, serta paparan dari radikal bebas. Salah satu cara untuk memelihara kesehatan hati adalah dengan pemberian hepatoprotektor. Hepatoprotektor adalah suatu senyawa atau zat yang berkhasiat melindungi sel sekaligus memperbaiki jaringan hati yang rusak akibat pengaruh zat toksik. Mekanisme kerja dari hepatoprotektor adalah dengan mendetoksifikasi senyawa racun baik yang masuk dari luar maupun yang terbentuk di dalam tubuh (Hadi 2002). Hepatoprotektor yang baik adalah hepatoprotektor dari bahan alam. Salah satu tanaman yang diduga memiliki efektivitas sebagai hepatoprotektor adalah petai (Parkia speciosa Hassk).

Petai (Parkia speciosa Hassk) merupakan salah satu tanaman yang dapat digunakan sebagai obat tradisional yang sudah lama ditanam di Indonesia. Petai merupakan pohon tahunan tropika dari suku polong-polongan. 
Secara tradisional biji petai digunakan untuk mengobati hipertensi, diabetes, ginjal serta me ngandung mineral dan vitamin. Biji petai juga memiliki aktivitas sebagai antibakteri dan antikanker (Kamisah 2013). Biji petai ini memiliki beberapa kandungan antara lain senyawa polifenol, fitosterol dan flavonoid, yang memungkinkan adanya aktivitas antioksidan pada biji petai. Aktivitas antioksidan pada petai telah diuji sebelumnya secara in vitro yang menunjukan adanya penghambatan oksidasi asam linoeat dengan persentase 47,55\%; 61,58\%; 73,04\%; dan 81,69\%, dengan konsentrasi ektrak berturut- turut 0,02; 0,04; 0,06; dan 0,08 mg/mL (Pahalaning 2007). Antioksidan adalah zat yang memperlambat atau menghambat stress oksidatif pada molekul target (Priyanto 2015). Salah satu zat yang dapat menyebabkan stress oksidatif adalah Karbon tetraklorida $\left(\mathrm{CCl}_{4}\right)$.

Karbon tetraklorida $\left(\mathrm{CCl}_{4}\right)$ merupakan zat yang tidak berwarna, berbau seperti eter atau kloroform dan dapat dicampur dengan alkohol, dietileter, benzene serta tidak mudah terbakar, mempunyai titik didih 76-77 ${ }^{\circ} \mathrm{C}$, dengan berat jenis $1,59 \mathrm{~g} / \mathrm{mL}$. Mekanisme kerusakan hati oleh $\mathrm{CCl}_{4}$ adalah karbon tetraklorida yang masuk ke dalam hati menjadi radikal triklorometil $\left(\mathrm{CCl}_{3}\right)$ oleh sitokrom P-450 diretikulum endoplasma, $\mathrm{CCl}_{3}$ ini akan bereaksi dengan $\mathrm{O}_{2}$ menjadi $\mathrm{CCl}_{3} \mathrm{O}_{2}$ (trikloro metal peroksi) yang lebih reaktif. Perubahan kimia dalam membran sel dapat menyebabkan membran sel pecah, sehingga enzim-enzim yang berada di dalamnya keluar lalu masuk ke dalam pembuluh darah, yang dapat menyebabkan peningkatan enzim transaminase dalam darah. Kerusakan akut maksimum pada hati tercapai dalam waktu 24-48 jam (Klaseen 2007). Tanda kerusakan hati Nampak jelas sebelum timbul efek pada ginjal. Walaupun berakibat fatal, tetapi lesi di hati tidak selalu mengakibatkan kematian.

Penelitian ini bertujuan untuk mengetahui efektivitas hepatoprotektor Ekstrak biji petai (Parkia speciosa Hassk). Parameter yang diamati adalah kadar SGPT dan SGOT serta histologi hati tikus. Dalam penelitian ini tikus akan diinduksi menggunakan $\mathrm{CCl}_{4}$, kemudian hasil kadar SGPT, SGOT, dan histologi hati akan dibandingkan dengan kontrol normal dan kontrol positif. Dasar pengujian ini adalah adanya antioksidan yang terkandung di dalam biji petai. Aktivitas antioksidan sebagai hepatoprotektor telah diuji sebelumnya pada tanaman yang berbeda, antara lain daun bakau api-api putih dengan konsentrasi $182 \mathrm{mg} / \mathrm{kg}$ (Hardiningtyas et al 2014), daun katuk (Sauropus androgynous L.) $800 \mathrm{mg} / \mathrm{kg} \mathrm{BB}$ (Joniada 2011), dan daun lidah buaya (Aloe vera L.) $4000 \mathrm{mg} / 200 \mathrm{~g} \mathrm{BB}$ (Kurniawan 2014). timbul efek pada ginjal. Walaupun berakibat fatal, tetapi lesi di hati tidak selalu mengakibatkan kematian.

\section{METODE}

\section{Tempat dan Waktu Penelitian}

Penelitian dilakukan pada bulan September hingga Oktober 2016 di Laboratotium Terpadu Fakultas Farmasi dan Sains Universitas Muhammadiyah Prof. Dr. Hamka Jakarta dan. Departemen Biologi Universitas Indonesia.

\section{Alat dan Bahan}

Alat-alat yang digunakan dalam penelitian ini terdiri dari : satu set alat bedah, kandang tikus putih, masker, sarung tangan, timbangan hewan, timbangan analitik, blender, hot plate, sonde, jarum suntik, erlenmeyer, beacker glass, gelas ukur, spatula, batang pengaduk, kaca arloji, rotary evaporator, kapas, kertas saring, termometer, tabung reaksi, mikrotube, mikropipet, tabung EDTA, pipan kapiler, cawan penguap, desikator, object glass, cover glass dan alumunium foil, spektofotometer klinikal. Bahan yang digunakan adalah biji petai 
(Parkia spesiosa Hassk), Kurliv Plus, HCl 2N, Aqua Destilata, larutan bouin, etelan, Pereaksi dragendort, Pereaksi Mayer, Metanol, $\mathrm{HCl}$ pekat, $\mathrm{Mg}$, Etanol 70\%, Eter, Asam Asetat Anhidrat, H2SO4 pekat, $\mathrm{FeCl}$, $\mathrm{NaCMC}, \mathrm{CCl} 4$, Reagen kit SGOT-SGPT.

\section{Prosedur Penelitian}

\section{Determinasi Tanaman}

Bahan yang digunakan adalah Biji Petai diperoleh dari BALITRO, Bogor. Determinasi dilakukan di Herbarium Bogoriense Bidang Botani Pusat Penelitian Biologi LIPI-Bogor.

\section{Pembuatan Ekstrak Etanol 70\% Biji Petai}

Biji petai ditimbang sebanyak $1 \mathrm{~kg}$ lalu dibersihkan kemudian dikeringkan di bawah sinar matahari hingga kering. Kemudian di serbuk dengan blender. Serbuk yang diperoleh diayak dengan pengayak mesh 40, kemudian ditimbang sebanyak $0,5 \mathrm{~kg}$ lalu disimpan dalam wadah bersih dan tertutup rapat. Simplisia biji petai diekstrak dengan cara maserasi dengan menggunakan pelarut etanol $70 \%$ ke dalam erlenmeyer selama 5 hari. Erlenmeyer kemudian ditutup kemudian sesekali diaduk. Campuran tersebut disaring dengan menggunakan kapas diatas corong sehingga didapatkan filtrat. Selanjutnya filtrat yang dihasilkan disaring kembali dengan kertas saring. Kemudian ampasnya dimaserasi kembali dengan menggunakan etanol sampai terlihat berwarna pucat. Filtrat yang diperoleh kemudian diuapkan dengan menggunakan rotary evaporator. Setelah diuapkan, ekstrak diuapkan dalam penangas air pada suhu $50^{\circ} \mathrm{C}$ sehingga diperoleh ekstrak biji petai kental.

\section{Pemeriksaan Karakteristik Ekstrak Biji Petai}

\section{Pemeriksaan organoleptis}

Pemeriksaan organoleptis meliputi pemeriksaan bentuk, warna, dan bau simplisia (Depkes RI 2000).

\section{Susut Pengeringan}

Pemerikaan dilakukandengan alat mosisture balance. Nyalakan moisture balance dan panaskan 10 menit. Setelah 10 menit atur alat dengan menekan menu, pilih metode yang akan digunakan. Masukan ekstrak kental kedalam wadah sampel didalam moisture balance dan ratakan. Tutup moisture balance kemudian tunggu hingga lampu mati dan catat hasilnya. Lakukan sebanyak 3x percobaan, kemudian ukur rata- ratanya. Tunggu alat hingga suhu $30^{\circ} \mathrm{C}$ dan matikan alat.

\section{Penapisan Fitokimia Ekstrak}

Uji penapisan fitokimia yang diujikan yaitu kandungan alkaloid, flavonoid, saponin, steroid dan triterpenoid, tanin (Depkes RI 1995).

\section{Perhitungan Rendemen Ekstrak Biji Petai}

Perhitungan rendemen dilakukan dengan menghitung jumlah ekstrak kering yang didapatkan kemudian dibagi dengan serbuk kering sebelum dilakukan ekstraksi, kemudian dikalikan 100\% (Depkes RI 2000).

\section{Penetapan Dosis}

Pada penelitian ini dosis ekstrak biji petai yang digunakan $50 \mathrm{mg} / 200 \mathrm{~g} \mathrm{BB}, 100 \mathrm{mg} / 200 \mathrm{~g} \mathrm{BB}, 200 \mathrm{mg} / 200 \mathrm{~g}$ BB. Penentuan dosis ini berdasarkan pada hasil dari pengujian aktivitas antioksidan biji petai terhadap antiinflamasi dengan dosis efektif 100 mg/200 g BB (Tanjaya Arifin 2015). 


\section{Pembuatan Sediaan Uji}

\section{Pembuatan Na CMC 0,5\%}

Menurut Farmakope Indonesia edisi IV $1 \mathrm{~g} \mathrm{Na}$ CMC larut dalam $50 \mathrm{~mL}$ air panas (Depkes RI 1995). Timbang $0,5 \mathrm{~g} \mathrm{Na}$ CMC, taburkan diatas $100 \mathrm{~mL}$ air panas, setelah 15 menit aduk kuat-kuat dalam lumpang sampai terbentuk suspensi yang homogen.

\section{Suspensi ekstrak Biji Petai}

Masukkan ekstrak biji petai dan Na CMC ke dalam lumpang gerus sampai homogen, kemudian masukkan ke dalam labu ukur tambahkan NaCMC sampai volume yang diinginkan, kocok sampai homogen.

\section{Perlakuan Terhadap Hewan Uji}

\section{Persiapan hewan uji}

Hewan uji yang digunakan adalah tikus Rattus norvegicus putih jantan berumur 2-3 bulan dengan berat badan 200-300 gram. Hewan tersebut diaklimatisasi terlebih dahulu selama 7 hari agar dapat menyesuaikan diri dengan lingkungan dan selama proses adaptasi dilakukan pengamatan kondisi umum serta dilakukan penimbangan berat badan setiap hari. Hewan uji yang sakit, dengan ciri-ciri aktivitas berkurang, lebih banyak diam, dan bulunya berdiri, tidak akan diikutsertakan dalam penelitian. Pengelompokan hewan uji yang sehat dilakukan sehari sebelum melaksanakan percobaan uji hepatoprotektor ekstrak biji petai.

\section{Pengambilan Serum Darah}

Pengambilan serum darah setelah perlakuan 8 hari diambil dari sinus orbital pada mata tikus menggunakan pipa kapiler pada hari ke-9, dimasukkan ke dalam tabung EDTA, dipindahkan ke dalam mikrotube, disentrifuge dengan kecepatan 4.500 rpm selama 15 menit sehingga didapatkan serum (bagian yang jernih) dari darah. Serum yang telah diperoleh diambil dengan menggunakan pipet ependrof kemudian dipisahkan ke tabung yang lain, untuk segera dilakukan pemeriksaan kadar SGOT dan SGPT.

\section{Pengukuran aktivitas SGOT dan SGPT}

\section{1) Pengukuran SGOT}

Serum darah diambil $100 \mu l$ dengan mikropipet, ditambahkan reagen SGOT BUF $1000 \mu l$, kemudian divortex, diinkubasi pada suhu $37^{\circ} \mathrm{C}$ selama 5 menit, kemudian ditambahkan reagen SGOT SUB $250 \mu l$, vortex dan diinkubasi pada suhu $37^{\circ} \mathrm{C}$ selama 1 menit. Ukur serapan pada spektrofotometer klinik.

\section{2) Pengukuran SGPT}

Serum darah diambil $100 \mu l$ dengan mikropipet, ditambahkan reagen SGPT BUF $1000 \mu l$, kemudian divortex, diinkubasi pada suhu $37^{\circ} \mathrm{C}$ selama 5 menit, kemudian ditambahkan reagen SGPT SUB $250 \mu l$, vortex dan di inkubasi pada suhu $37^{\circ} \mathrm{C}$ selama 1 menit. Ukur serapan pada spektrofotometer klinik

\section{Analisis Data}

Data yang telah terkumpulkan, diolah dengan menggunakan uji distribusi normal (uji Kolmogorov-smirnov), uji homogenitas (uji levene), lalu dilanjutkan dengan analisis varian satu arah (ANOVA) untuk mengetahui perbedaan yang ada, jika terdapat perbedaan dua perlakuan atau lebih (nilai sig. < 0.005) maka pengujian dilanjutkan dengan uji Tukey untuk mengetahui letak perbedaannya (Budi dan Ashari 2005). 


\section{HASIL DAN PEMBAHASAN}

\section{Hasil Determinasi}

Biji petai dari dari tanaman petai diperoleh dari Blittro Bogor, dideterminasi di Herbarium Bogoriense, Bidang Botani Pusat Penelitian Biologi LIPI Bogor. Hasilnya menunjukkan bahwa tanaman tersebut adalah Parkia spesiosa Hassk yang termasuk ke dalam keluarga Fabaceae / Leguminosae

\section{Hasil Ekstrak}

Biji petai segar ditimbang $1 \mathrm{~kg}$ kemudian dikeringakan di bawah sinar matahari. Biji petai yang telah kering dibuat menjadi serbuk untuk mempermudah proses ekstraksi dan diayak dengan ayakan mesh 40. Ditimbang serbuk biji petai 500 gram, dimasukkan ke dalam wadah maserasi tambahkan pelarut etanol $70 \%$ dengan perbandingan 1:10. Hasil maserasi dipekatkan dengan rotary evaporator hingga mendapat ekstrak kental. Dari hasil ekstraksi biji petai didapat data sebagai berikut:

\section{Tabel 1.}

Hasil Ekstraksi Biji Petai

\begin{tabular}{clc}
\hline No & \multicolumn{1}{c}{ Jenis } & Hasil \\
\hline 1 & Biji petai segar & $1 \mathrm{~kg}$ \\
2 & Biji petai kering & $0,89 \mathrm{~kg}$ \\
3 & Serbuk biji petai & $0,5 \mathrm{~kg}$ \\
4 & Ekstrak biji petai & $125,69 \mathrm{gram}$ \\
\hline
\end{tabular}

\section{Hasil Karakteristik Ekstrak}

Ekstrak kental yang didapat diuji karakteristiknya melalui uji organoleptis yang mencakup warna, bau, bentuk, dan rasa, kemudian perhitungan rendemen ekstrak dan kadar air yang terkandung didalam ekstrak dengan metode susut pengeringan. Dari hasil pengujian tersebut didapat data sebagai berikut:

Tabel 2.

\section{Karakteristik Ekstrak Etanol Biji Petai}

\begin{tabular}{cc}
\hline Organoleptis & Warna : hijau tua pekat \\
\cline { 2 - 2 } & Bau : khas \\
\cline { 2 - 2 } & Bentuk : kental \\
\hline Rasa $:$ khas \\
\hline Susut pendemenen & $25,138 \%$ \\
\hline
\end{tabular}

\section{Hasil Penapisan Fitokimia}

Pada ekstrak dilakukan penapisan fitokimia yang meliputi uji alkaloid, saponin, steroid dan triterpenoid, serta tanin. Didapatkan hasil bahwa ekstrak mengandung alkaloid, flavonoid, saponin, steroid, dan tidak mengandung terpenoid dan tannin. Berikut hasil penapisan fitokimia ekstrak biji petai. 
Tabel 3.

Hasil Uji Penapisan Fitokimia Ekstrak Biji Petai

\begin{tabular}{lc}
\hline Kandungan & Ekstrak Etanol \\
Alkaloid & + \\
Flavonoid & + \\
Saponin & + \\
Steroid & + \\
Triterpenoid & - \\
Tanin & - \\
\hline
\end{tabular}

\section{Hasil Uji Efektivitas Hepatoprotektor}

Setelah hewan uji diberi ektrak dan perlakuan sesuai dengan kelompok masing- masing selama 7 hari, kemudian hewan uji diinduksi dengan $\mathrm{CCl}_{4}$ pada hari kedelapan dan dilakukan pengambilan darah pada hari kesembilan. Dari hasil pengujian yang dilakukan didapat hasil kadar SGPT dan SGOT tikus putih jantan sebagai berikut:

Tabel 4.

Rerata kadar SGPT dan SGOT Tikus Putih Jantan

\begin{tabular}{lcc}
\hline Perlakuan & Kadar SGPT $(\mathbf{m U} / \mathbf{m L})$ & Kadar SGOT $(\mathbf{m U} / \mathbf{m L})$ \\
\hline Kontrol normal & $23,25 \pm 7,45$ & $29 \pm 7,61$ \\
Kontrol positif & $25 \pm 2,94$ & $30 \pm 3,74$ \\
Kontrol negatif & $50,75 \pm 8,77$ & $59,5 \pm 10,36$ \\
Dosis 1 $(50 \mathrm{mg} / 200 \mathrm{~g} \mathrm{BB})$ & $18 \pm 4,39$ & $23,5 \pm 3,87$ \\
Dosis 2 $(100 \mathrm{mg} / 200 \mathrm{~g} \mathrm{BB})$ & $21 \pm 4,96$ & $26,26 \pm 4,78$ \\
Dosis 3 $(200 \mathrm{mg} / 200 \mathrm{~g} \mathrm{BB})$ & $23,5 \pm 3,11$ & $29,75 \pm 1,71$ \\
\hline
\end{tabular}

Tabel 5.

Rata- rata Diameter Vena Sentralis

\begin{tabular}{ll}
\hline \multicolumn{1}{c}{ Perlakuan } & \multicolumn{1}{c}{$\begin{array}{c}\text { Diameter rata- rata vena } \\
\text { sentralis }(\boldsymbol{\mu m})\end{array}$} \\
\hline Kontrol normal & $0,3425 \pm 0,015$ \\
Kontrol positif & $0,32 \pm 0,029$ \\
Kontrol negatif & $0,7125 \pm 0,043$ \\
Dosis 1 $(50 \mathrm{mg} / 200 \mathrm{~g} \mathrm{BB})$ & $0,4575 \pm 0,047$ \\
Dosis 2 $(100 \mathrm{mg} / 200 \mathrm{~g} \mathrm{BB})$ & $0,4375 \pm 0,012$ \\
Dosis 3 $(200 \mathrm{mg} / 200 \mathrm{~g} \mathrm{BB})$ & $0,335 \pm 0,042$ \\
\hline
\end{tabular}

Pengukuran kadar SGPT dan SGOT menggunakan Spektrofotometer Klinikal. Dari data yang diperoleh, dilakukan uji homogenitas dan normalitas (Kosmogorov-Smirnov) didapat nilai $\mathrm{P}>0,05$ yang memberi kesimpulan bahwa data terdistribusi normal dan homogen. Selanjutnya dilakukan uji ANOVA satu arah didapat $\mathrm{P}<0,05$, hasil tersebut menunjukan adanya efektivitas ekstrak biji petai sebagai hepatoprotektor. Selanjutnya untuk mengetahui perbedaan yang ada, analisa dilanjutakan dengan uji Tukey HSD. Dari tabel 4 di atas untuk kontrol negatif didapatkan hasil kadar SGPT (50,75 $\pm 8,77 \mathrm{mU} / \mathrm{mL})$ dan SGOT (59,5 $\pm 10,36 \mathrm{mU} / \mathrm{mL})$. Hasil uji statistik menunjukkan perbedaan yang bermakna dengan semua kelompok perlakuan. Hal ini disebabkan karena kontrol negatif hanya diberi induksi dengan $\mathrm{CCl}_{4}$ tanpa pemberian obat. Pada saat pemberian $\mathrm{CCl} 4$ sel hati menjadi rusak. $\mathrm{CCl} 4$ di dalam hati dimetabolisme fase 1 menjadi $\mathrm{CCl} 3$ yang bereaksi dengan $\mathrm{O} 2$ menjadi $\mathrm{CCl} 3 \mathrm{O} 2$ yang bersifar radikal bebas, senyawa ini memperoksidasi rantai asam lemak dari membran sel yang menyebabkan perubahan permeabilitas membran sel hati dan membran sel endotel pada vena sentralis. Setelah terjadi peroksidasi, rantai membran sel lisis menjadi rusak, sehingga enzim SGPT dan SGOT yang terdapat 
didalam sel hati keluar dan masuk ke dalam sirkulasi darah, yang menyebabkan peningkatan kadar SGPT dan SGOT di dalam darah. Pengujian dilanjutkan dengan pengukuran rerata diameter vena sentralis. Pengukuran rerata diameter vena sentralis dilakukan dengan mikroproyektor di dalam ruang gelap. Dari data yang diperoleh, dilakukan uji homogenitas dan normalitas (Kosmogorov-Smirnov) didapat nilai $\mathrm{P}>0,05$ yang menunjukkan bahwa data terdistribusi normal dan homogen. Selanjutnya dilakukan uji ANOVA satu arah didapat $\mathrm{P}<0,05$, hasil tersebut menunjukan adanya efektivitas ekstrak biji petai sebagai hepatoprotektor. Selanjutnya untuk mengetahui perbedaan yang ada dilanjutakan dengan uji Tukey HSD.

Dari tabel 5 didapatkan hasil rerata vena sentralis kontrol negatif $(0,7125 \pm 0,043 \mu \mathrm{m})$, dosis $1(0,4575 \pm 0,047$ $\mu \mathrm{m})$, dan dosis $2(0,4375 \pm 0,012 \mu \mathrm{m})$. Hasil uji statistik menunjukan bahwa terdapat perbedaan bermakna antara kontrol negatif, dosis 1 , dan dosis 2 dengan kontrol normal, kontrol positif, dan dosis 3. Dapat disimpulkan bahwa dosis $3(0,335 \pm 0,042 \mu \mathrm{m})$ memiliki efektivitas yang sama dengan kontrol normal $(0,3425$ $\pm 0,015 \mu \mathrm{m})$ dan kontrol positif $(0,32 \pm 0,029 \mu \mathrm{m})$. Dari hasil semua data yang ada, dapat ditarik kesimpulan bahwa ekstrak biji petai memiliki efektivitas sebagai hepatoprotektor dengan dosis efektif dosis 3 (200 mg/200 g BB), hal ini didukung dengan data statistik rerata diameter vena sentralis yang menunjukan tidak adanya perbedaan antara dosis 3 dengan kontrol normal dan kontrol positif, sedangkan dosis 1, dosis 2, dan kontrol negatif terdapat perbedaan yang bermakna.

\section{Hasil Histopatologi Hati}

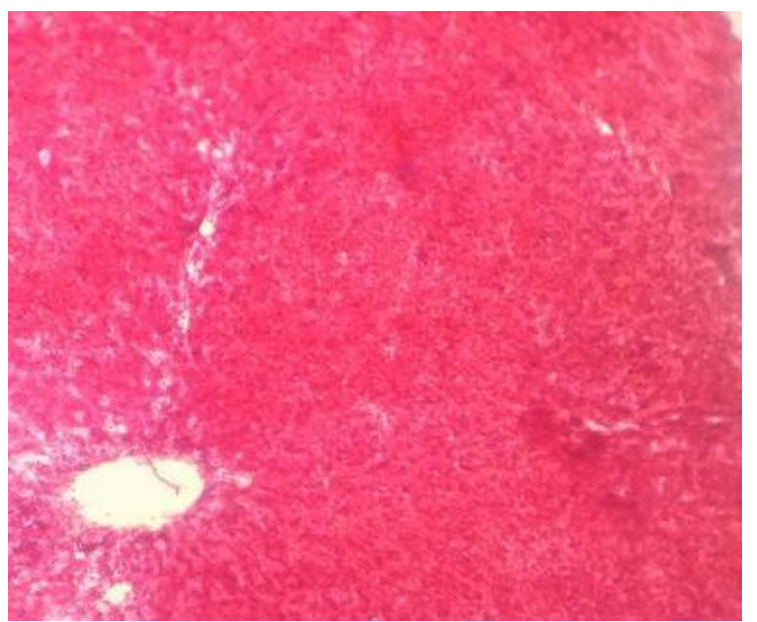

Gambar 1. Kontrol normal (a. vena sentralis ; b. sinusoid)

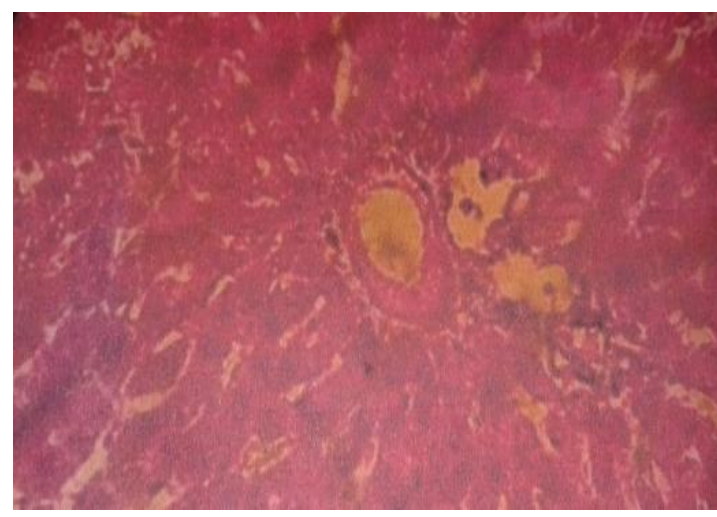

Gambar 3. Kontrol negatif (a. Vena sentralis ; b. sinusoid)

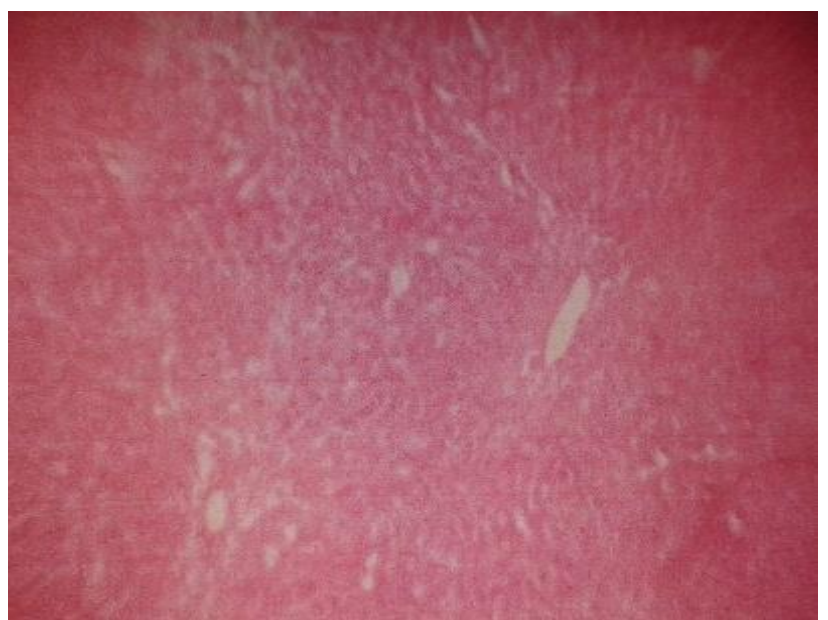

Gambar 2. Kontrol positif (a. vena sentralis ; b. sinusoid)

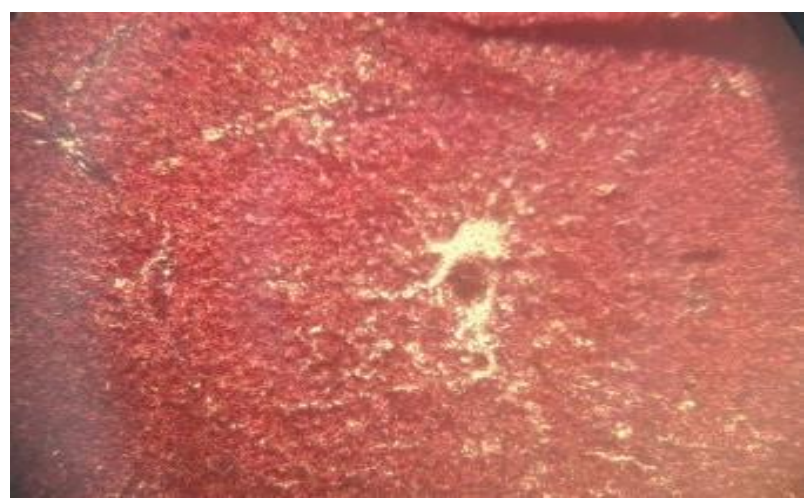

Gambar 4. Dosis 1 (a. vena sentralis ; b. sinusoid) 


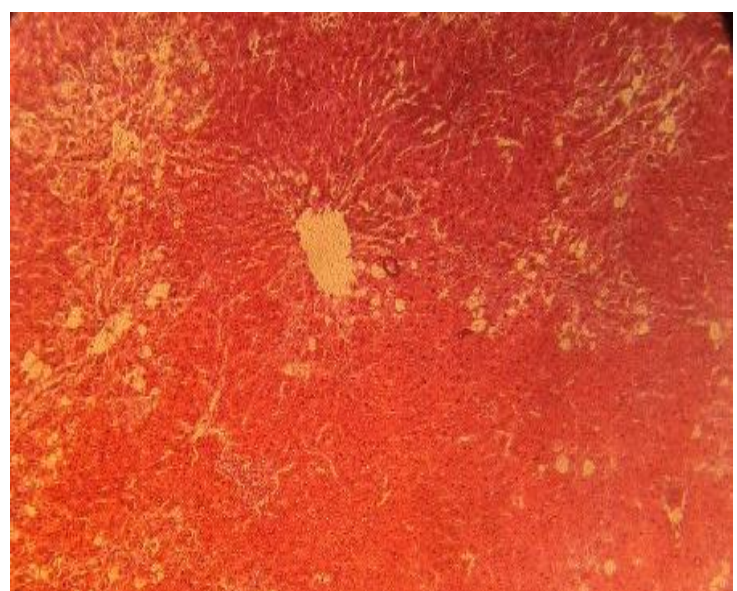

Gambar 5. Dosis 2 (a. vena sentralis; b. sinusoid)

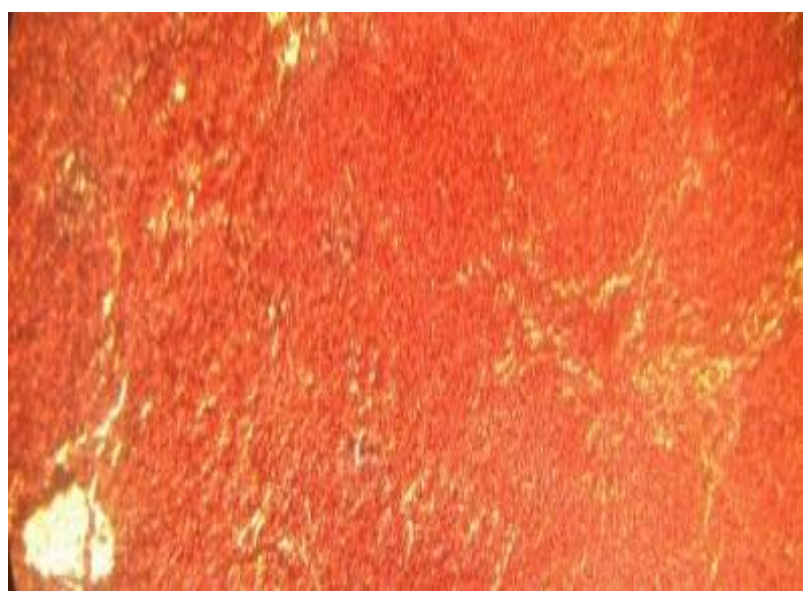

Gambar 6. Dosis 3 (a. vena sentralis ; b. sinusoid)

\section{KESIMPULAN DAN REKOMENDASI}

Dari penelitian yang dilakukan dapat disimpulkan bahwa biji petai (Parkia spesosa Hassk) memiliki efektivitas sebagai hepatoprotektor dengan dosis efektiv 200mg/200g BB. Hal ini ditunjukan dari hasil data statistik rerata kadar SGPT dan SGOT yang menunjukan tidak adanya perbedaan antara dosis $3(23,5 \pm 3,11)$ untuk SGPT dan $(29,75 \pm 1,71)$ untuk SGOT dengan kontrol normal $(23,25 \pm 7,45)$ untuk SGPT dan $(29 \pm 7,61)$ untuk SGOT serta kontrol positif $(25 \pm 2,94)$ untuk SGPT dan $(30 \pm 3,74)$ untuk SGOT, dan didukung dengan data statistik rerata diameter vena sentralis yang menunjukan tidak adanya perbedaan bermakna antara dosis $3(0,335 \mu \mathrm{m} \pm$ $0,042)$ dengan kontrol normal $(0,3425 \mu \mathrm{m} \pm 0,015)$ dan kontrol positif $(0,32 \mu \mathrm{m} \pm 0,029)$, sedangkan pada dosis 1 $(0,4575 \mu \mathrm{m} \pm 0,047)$, dosis $2(0,4375 \mu \mathrm{m} \pm 0,012)$, dan kontrol negatif $(0,7125 \mu \mathrm{m} \pm 0,043)$ terdapat perbedaan yang bermakna. Rekomendasi yang perlu dilakukan penelitian lebih lanjut terhadap toksisitas ekstrak biji petai untuk dapat diimplementasikan sebagai obat dan perlu diusahakan agar dosis yang digunakan dapat diperkecil dengan cara fraksinasi, isolasi zat aktif isolasi dan semisintesis.

\section{REFERENSI}

1. Anief, M. 2000. Ilmu Meracik Obat. Gajah Mada University Press. Yogyakarta. Hlm. 168-169 Baradero M, et al. 2008. Klien Gangguan Hati : Seri Asuhan Keperawatan. ECG. Jakarta. Hlm.1-19

2. Departemen Kesehatan RI. 2000. Parameter Standar Umum Ekstrak. Jakarta: Direktorat Jendral Pengawasan Obat dan Makanan. Hlm.11-13

3. Departemen Kesehatan RI, 1995. Farmakope Indonesia. Edisi IV. Badan Pengawas Obat dan Makanan. Jakarta. Hlm 175

4. Depkes RI. 2008. Farmakope Herbal Indonesia. Edisi 1. Jakarta: Departemen Kesehatan RI. Hlm 170

5. Eroschenko V. P. 2003. Atlas Histology di Fiore dengan Korelasi Fungsional Edisi 9.Jakarta: EGC. Hlm. 215.

6. Fakultas Kedokteran Universitas Indonesia. 1995. Farmakologi dan Terapi. Jilid IV. Departemen Farmakologi dan Terapeutik FKUI. Jakarta. Hlm. 777

7. Hadi, S. 2002. Hepatologi. Mandar Maju. Jakarta. Hlm.174-195 
8. Hardiningtyas Safrina D, dkk. 2014. Aktivitas Antioksidan dan Efek Hepatoprotektif Daun Bakau ApiApi Putih. JPHPI. Vol. 17, no. 1, Hlm. 80

9. ITIS Standart Report Parkia speciosa Hassk Taxonomic Hierarchy. http://www.itis.gov/servlet/SingleRpt/SingleRpt?search_topic=TSN\&search_value=506261 . Diakses 26 Maret 2016

10. Joniada, I Made. 2011. Pengaruh Pemberian Ekstrak Etanol Daun Katuk (Sauropus androgynous L.) Sebagai Hepatoprotektor Pada Mencit Yang di Induksi Parasetamol. Skripsi. Fakultas Farmasi Universitas Jember, Jember. Hlm. 39

11. Kamisah, Y. et al. 2013.’Parkia speciosa Hassk : A Potential Pytomedicine”. Journal International. Volume 2013. Page 9

12. Klaassen D. Curtis. 2007. Dasar Farmakologi Terapi. Edisi 10. Terjemahan : Tim Alih Bahasa sekolah farmasi ITB. Buku Kedokteran EGC. Jakarta. Hlm.1850

13. Pahalaning W. I 2007. Uji Aktivitas Antioksidan Dari Ekstrak Etanol 70\% Biji Petai (Parkia spesiosa Hassk) Secara In Vitro. Universitas Negeri Yogyakarta, Yogyakarta. http://eprints.uny.ac.id/2672. Diakses 25 Mei 2016

14. Priyanto, 2015. Toksikologi. LESKONFI, Depok. Hlm.98-101

15. Sadikin M. 2002. Biokimia Enzim. Widya Medika, Jakarta. Hlm. 287-309

16. Setiadi. 2007. Anatomi dan Fisiologi Manusia. Edisi I. Graha Ilmu. Yogyakarta. Hlm. 80-81

17. Steven A, Lowe J. 2005. Human Histology 3rd Edition. Philadelphia: Elsevier Saunders. Hlm.230. 14

18. Tanjaya, Arifin. 2015. Uji Aktivitas Antiinflamasi dan Antipiretik Ekstrak Etanol Biji Petai (Parkia speciosa Hassk) Pada Tikus Putih Jantan Galur Wistar. Naskah Publikasi. Fakultas Kedokteran Universitas Tanjungpura, Pontianak 